\title{
BAIL BEFORE TRIAL: \\ REFLECTIONS OF A SCOTTISH LAWYER
}

\section{T. B. SMITH +}

Links between Scots law and the Law School of the University of Pennsylvania are of long standing. Indeed, as Professor Nadelmann has noted recently, James Wilson, a Scottish-born member of the Supreme Court of the United States, referred to Scottish sources frequently, when delivering his Lectures on Law in the University of Pennsylvania in 1790. Shortly before the late Dr. Edwin R. Keedy assumed his duties as professor at that University-where for fortyfour years he was to do pioneer work in the field of comparative criminal law and procedure-he had applied himself to a serious study of Scottish criminal procedure. The fruits of this early research were published in 1913, ${ }^{2}$ and his reputation has always stood high among Scottish lawyers. Witness, for example, the reference to Keedy's researches in the Stair Society's publications. ${ }^{3}$

It is proposed to examine in this paper-dedicated to the memory of Dr. Keedy-the operation of bail in Scottish practice, and to contrast it with the English system in particular. To understand Scottish practice regarding bail, some knowledge of Scottish criminal law and procedure in general is desirable. This can scarcely be assumed in a learned journal which will be read by those who, for the most part, have been trained in the Anglo-American common law. Fortunately, Dr. Keedy himself has in his earlier writings explained Scottish criminal procedure to the American reader." What he wrote in 1913 is still substantially true, though there have been important changes during the past forty-six years, and recent historical research has discounted certain views related to and narrated by Dr. Keedy regarding the earlier period of Scots law. So far as the modern law alone is concerned, his account written before the First World War has been superseded particularly in relation to appeal, outlawry and declarations at judicial examination. Appeal is now competent from conviction on

tQueen's Counsel; Fellow of the British Academy; Professor of Civil Law, University of Edinburgh. M.A., D.C.L., LL.D. The author is deeply grateful for the criticism and helpful advice offered by the President of Queens College, Cambridge, by Sheriff A. M. Prain and others.

1 Nadelmann, Joseph Story and George Joseph Bell, 1959 Jorm. Rev. 31. (1913).

2 Keedy, Criminal Procedure in Scotland (pts. 1-2), 3 J. CRTM. L. \& C. 728, 834

31 Selected Justiciary Cases 1624-1650 242 (Stair Society Pub. 16, 1953).

4 See note 2 supra. 
indictment in the High Court of Justiciary, "outlawry" is abolished, and declaration by an accused at what is still rather misleadingly called "judicial examination" is virtually obsolete."

The reader may refer generally to Dr. Keedy's celebrated article and to the standard works on Scottish criminal law and procedure. ${ }^{8}$ A few brief observations on the foundations and principles of Scottish criminal procedure must suffice for present purposes. When the separate kindgdoms of Scotland and England agreed to merge (from the viewpoint of international law) in the new State of Great Britain on May 1,1707, the terms of union were set out in certain documents which had effect as an international treaty, as legislation within the several jurisdictions of Scotland and England and also as a constituent agreement. Though skeletal in form, there is a written constitution for Great Britain, limiting in certain respects the powers of the new Parliament of Great Britain which replaced the former Parliaments of Scotland and England. ${ }^{9}$ In particular, safeguards were provided for Scots law and for the Scottish judicial system, which, without such protection, would have been liable to undue pressure from English law to assimilate with it. Scotland, in the 18th century, shared with the rest of civilized Europe the heritage of Roman law; English law was an original and semi-insular system. In 1707 it can scarcely be doubted that the civil law of Scotland, as restated by Stair in 1681 under the influence of the natural law school, was greatly superior in quality to the English common law of the same period, which was then passing through an arid and formalistic epoch. Scottish criminal law and procedure at the same period had not reached the same state of maturity. Paradoxically, Scottish criminal law has benefited by its relatively late development, and has achieved a flexibility which English criminal law-at one time more mature-lost through early crystallization by precedent. Moreover, since the High Court of Justiciary in Edinburgh is the ultimate tribunal in all Scottish criminal causes, there has been no opportunity given to the House of Lords (as judicial organ of the United Kingdom Parliament) to impose English solutions

5 Criminal Appeal (Scotland) Act, 1926, $16 \& 17$ Geo. 5, c. 15.

${ }^{6}$ Criminal Justice (Scotland) Act, 1949, 12, 13 \& 14 Geo. 6, c. 94, § 15(2).

7 Renton \& Brown, Criminal Procedure According to the Law of Scotland 31 (3d ed. 1959). See also SmrxH, United Kingdom: Scotland 764-66, in THE Britis H COMMONWEAlth-The DeVELOPMENT OF ITS LAWS and Constitutions (1955); Smith, Public Interest and the Interests of the Accused in the Criminal Process-Reflections of a Scottish Lawyer, 32 Tux. L. REv. 349, 362-63 (1958).

8 Macdonald, Criminal Law of Scotland (5th ed. 1948); Renton \& Brown, op. cit. supra note 7; Lord Normand, The Public Prosecutor in Scotland, 54 L.Q. Rev. 345 (1938); Scottish Judicature and Legal Procedure (Holdsworth Club of Univ. of Birmingham 1941). See also SMrTH, op. cit. supra note 7, at c. 28.

8 This is more fully developed by the writer in The Union of 1707 as Fundamental Law, 1957 PUB. L. 99. 
on Scots law. Such influence as English criminal law has had on Scots law has been through true comparative methods.

Scottish substantive criminal law-except for the relatively small contribution of statute-derives from the practice of the courts, influenced to some extent by the civil and canon law and mediated through the institutional writers and Justiciary reports. Scottish criminal procedure, though worked out in the practice of the Justiciary Court, is largely based on statute-in particular, the Criminal Procedure (Scotland) Act, $1887,,^{10}$ so far as indictable crimes are concerned, while the Summary Jurisdiction (Scotland) Act, 1954, ${ }^{11}$ regulates summary procedure. The pivot of the administration of criminal justice in Scotland is the office of Lord Advocate-which is invested with extensive powers and discretion. Though private prosecution may be competent in rare cases, no private prosecution for serious crime has taken place since $1909 .{ }^{12}$ Here Scottish practice differs greatly from that of England, where prosecutions are not normally undertaken by an official public prosecutor. In England the basic principle underlying prosecution is that it is open to any member of the public to institute proceedings, and he need not have any interest whatever in the subject matter of the charge. When a person in public employment, such as a police officer, prosecutes, he does so as "a member of the public"-but such prosecutions, though not undertaken by a public prosecutor, are usually contrasted with "private prosecutions" instituted by private citizens. ${ }^{13}$ Criminal prosecution in Scotland is the concern of the Lord Advocate, assisted by the Solicitor-General for Scotland, six Advocates-Depute and by the permanent officials of the Crown Office. In the sheriffdoms ${ }^{14}$ the Lord Advocate has also his representatives, Pro-

1050 \& 51 Vict., c. 35.

112 \& 3 Eliz. 2, c 48.

12 J. \& P. Coats, Ltd. v. Brown, (1909) 6 Adam 19, [1909] Sess. Cases 29 (Justiciary).

13 Jackson, The Machinery of Justice in England 108 (2d ed. 1953).

14 Scotland is divided for judicial and for some administrative purposes into Sheriffdoms. Formerly each county was a separate Sheriffdom, but amalgamations of the less populous counties have reduced the number of Sheriffdoms to twelve. To each of these a Sheriff-Principal is appointed, but in the principal towns of each Sheriffdom there are resident Sheriffs who handle the great bulk of judicial business. The Sheriff Court is an initial trial court which in most civil matters has concurrent jurisdiction (without monetary limitation) with the Outer House of the Court of Session. Though his powers of punishment are normally limited to two years' imprisonment, the Sheriff may try all crimes and offences committed within the Sheriffdom, except for a small number which are excluded-such as treason, murder, attempt to murder, rape, incest, and offences under the Official Secrets Acts. Appeals lie from the Sheriff Court exercising criminal jurisdiction to a quorum of Judges of the High Court of Justiciary, Scotland's superior criminal court. This court comprises fifteen judges who are also (in the capacity of Senators of the College of Justice) the judges of the Court of Session, Scotland's superior civil court. In civil, though not in criminal matters, an appeal may be carried to the House of Lords where judicial functions are exercised by a Judicial Committee comprising eminent Scottish, English and Irish judges. 
curators-Fiscal, to whom he issues instructions and delegates certain powers of investigating and prosecuting crime. The Lord Advocate has wide discretion as to when to prosecute-or abandon prosecution. $\mathrm{He}$ is ultimately answerable for his decisions in Parliament, but cannot be compelled to act contrary to his judgment. Provision is made in Scottish practice for both prosecution and defense to have notice within limits of the case to be put forward at trial by the other side, but this is not achieved by calling evidence in a preliminary judicial enquiry. Pre-trial procedure in Scotland is quasi-inquisitorial, in the sense that there is no "hearing" as in England or the United States to ascertain whether a suspect should be committed for trial. The Crown Office and Procurators-Fiscal in Scotland will prepare the case -precognoscing witnesses and preparing a dossier for trial; and, if eventually they are not satisfied that the evidence against a suspect would justify conviction, they may drop proceedings and cause the suspect to be released, if he is in custody awaiting trial.

A study of the theory and practice of bail in the United States, Scotland and England discloses certain fundamental similarities and also a number of important differences. Important surveys of the administration of bail in New York and Philadelphia have been undertaken recently by students of the University of Pennsylvania Law School. ${ }^{15}$ Each stresses that the right to bail before trial in non-capital cases is guaranteed by constitutional law. The Supreme Court of the United States has observed, "Unless this right to bail before trial is preserved, the presumption of innocence, secured only after centuries of struggle would lose its meaning." ${ }^{18}$ The learned author of the "Comment on the New York Bail Study" contends, moreover, that in United States practice the sole consideration in granting bail is to ensure that the defendant will appear for trial; other factors taken into account by British and continental systems, such as likelihood of tampering with evidence or of committing criminal acts after bail and pending trial, are not in theory relevant in American practice. "[T]he spirit of the procedure is to enable [defendants] to stay out of jail until a trial has found them guilty.' Beside the fact that such a policy is implicit in the presumption of innocence, the soundness of our theory will be apparent to anyone who contemplates the almost insuperable difficulty of trying to contact witnesses and prepare and finance a defense from the enforced idleness of a prison cell." 17

15 Note, $A$ Study of the Adnitistration of Bail in New York City, 106 U. PA. L. REv. 693 (1958); Note, Compelling Appearance in Court: Administration of Bail in Philadelphia, 102 U. PA. L. REv. 1031 (1954).

16 Stack v. Boyle, 342 U.S. 1, 4 (1951).

17 Foote, Forward: Comment on the New York Bail Study, 106 U. PA. L. REv. 685,686 (1958). 
Other legal systems, such as those of Scotland and England are liberal in their practice of awarding bail, but they do not restrict themselves to consideration merely of what security (usually financial) will ensure the appearance of an accused at his trial. The public interest is weighed as well as that of the individual suspect, and-in the present writer's view-properly so. The "presumption of innocence," in Britain at all events, is a rule of evidence to secure fair trial, and implies that the guilt of an accused must be proved at his trial beyond all reasonable doubt. It does not mean that those who discharge executive or administrative functions prior to trial should be bound to act as though the suspect had behaved, and would pending trial behave, as a law-abiding citizen. This would be to contradict the experience of mankind over the ages. To take extreme examples-the householder who apprehends the housebreaker rifling his desk, and the police officer who arrests the armed robber, weapon in hand, by the corpse of his victim, have no doubt about the guilt of the accused; the public prosecutor or judge who has to determine whether bail should be granted in such cases (and has considered the evidence of eye witnesses) may well have little doubt that the accused has committed the acts alleged against him. It is not, however, for them to determine the question of guilt or innocence. This is the province of the trial court. Pressed to extremes, the presumption of innocence would preclude arrest and pre-trial custody altogether, and, incidentally, entirely frustrate extradition proceedings. Moreover, it has been established by experience again and again that those who are known to have committed particular crimes in the past-such as theft by housebreaking-and are accused of yet another such crime, are all too prone to avail themselves of a period of release on bail to ensure that they do not hang for a lamb. Further, tampering with evidence and intimidation of witnesses does happen, and the duty to ensure fair trial and vindication of justice is not concerned with the interests of the accused alone. The considerations which would justify the granting or refusing of bail in the 20th century are not necessarily identical with those of the 18th century when executive and judicial arrangements were less efficient, and when prison conditions in general were appalling. The 21 st century in its turn may well bring forth new factors to be weighed.

Since English criminal law and procedure provided the foundation for the various systems operating in the United States, it may be convenient before proceeding to a fuller discussion of the Scottish system, to make brief mention of present practice regarding the granting of bail in England. No historical introduction is necessary for an American lawyer to understand it. Bail in treason is discretionary and may 
only be granted by a Secretary of State or by a judge of the High Court. ${ }^{18}$ Examining justices have power to grant bail to all persons committed for trial for any felony or misdemeanour, but there is no absolute obligation to grant bail. ${ }^{18}$ A person who is refused bail by the justices may apply to a judge of the High Court who may grant it ; and if (except in cases of treason or murder) the examining magistrates commit a person for trial without releasing him on bail, they must inform him of his right to apply for bail to a judge of the High Court. ${ }^{20}$ A judge of the High Court has, however, no inherent jurisdiction to reduce the amount of bail where the justices in the exercise of their statutory powers have fixed bail in a specified sum; but, if that sum is so excessive that the prisoner cannot avail himself of it, application may be made to a Divisional Court for a writ of habeas corpus, on the ground that the imposition of such excessive bail amounts to an unlawful refusal of bail, and, contravening the Bill of Rights, 1689, ${ }^{21}$ makes the imprisonment of the applicant unlawful. ${ }^{22}$ The effect of habeas corpus procedure and of the Assizes Relief Act, 1889, ${ }^{23}$ English lawyers have claimed hitherto, is that a person cannot be kept long in confinement against his will, but can secure either speedy trial or release on bail. However, the case of $R$. $v$. Campbell ${ }^{24}$ last year indicates that the Habeas Corpus Act ${ }^{25}$ affords a much less effective guarantee of speedy trial than had been thought. ${ }^{26}$ Laski, J., considered that it may be "difficult, if not impossible, to comply with the requirements of the statute." 27 Certainly if the courts were to insist on strict

18 Magistrates' Courts Act, 1952, 15 \& 16 Geo. 6 \& 1 Eliz. 2, c. 55, §8.

19 Magistrates' Courts Act, 1952, 15 \& 16 Geo. 6 \& 1 Eliz. 2, c. 55, §7(2).

20 Magistrates' Court Rules, 1952, rule 9, [1952] 2 Stat. InsTr. 1598 (No. 2190). 211 W. \& M., c. 2.

22 Ex Parte Thomas, 1956 CRIM. L. REv. (Eng.) 119 (Q.B. 1955) ; R. v. Campbell, [1959] 1 Weekly L.R. 646 (Liverpool Crown Ct.).

$2352 \& 53$ Vict., c. $12, \S 3$.

24 [1959] 1 Weekly L.R. 646 (Liverpool Crown Ct.).

25 Habeas Corpus Act, 1679, 31 Car. 2, c. 2, §6.

26 Campbell and two other persons were committed for trial in December 1958 on a charge of robbery. In January 1959, the two others pleaded guilty, and were sentenced, but Campbell pleaded not guilty. On this occasion, and again in February 1959, the prosecution applied for the trial to be postponed because an essential prosecution witness (a seaman) was out of the country. In March 1959, when it became known that this witness could not return until July, the prosecution asked for a direction whether an application for respite should be made in each session until July or whether the court could there and then order that the trial be respited until July. The issue of bail arose indirectly out of this application by the prosecution. The Recorder held that the Habeas Corpus Act did not apply, because the application had been made by the prosecution, and not, as required in the act, by the defence; and moreover, because Campbell had not complied with the somewhat complicated procedural conditions precedent laid down in that act. It was no longer possible for him so to apply, but the judge exercised a discretionary power (not dependent on the Habeas Corpus Act) to order that the case should lie on the file, and that no further proceedings be taken without leave of the court. Campbell was then released from custody.

271 Weekly L.R. at 650. 
compliance with the procedural requirements of the act, this would deny a remedy to any prisoner who had expected to be, but had not in fact been, brought to trial during the first session after committal. The Attorney-General has indicated that legislation will be hastened on to remedy this situation, and, as this will be a question of English law reform, presumably Parliament will find time for it.

This much is trite law. In fact, of course, the vast majority of all prosecutions in England-perhaps 99 per cent-are dealt with by magistrates within a few days, and in nearly all such cases the accused is allowed to be at liberty until his trial. If he is accused of certain offenses triable by the justices, has been arrested without warrant, and has not been brought before a magistrate within twenty-four hours, his right to liberation on bail is absolute. ${ }^{28}$ So far as serious offenses are concerned, arrest is usually upon warrant, and in such cases there may well be delay. When the suspect is first brought before the magistrates, the prosecution may wish more time to prepare their case and ask for him to be remanded. Though this may not be for more than eights days at a time, ${ }^{29}$ there may be several periods of remand, and at this stage the granting of bail is in the magistrates' discretion. If eventually the prosecution establish a prima facie case before the examining justices, and the accused is committed for trial, again the magistrates must exercise their discretion as to whether bail should be granted or refused. If bail is refused at any time before committal, or after committal but before trial, the accused may appeal to a judge of the High Court-which involves the serving of a summons both on the prosecution and on the magistrate refusing bail.

The leading treatise on English criminal practice ${ }^{30}$ states: "The requirements as to bail are merely to secure the attendance of the defendant at the trial . . . . The proper test of whether bail should be granted or refused is whether the accused person will appear to take his trial." 31 This test, it is said, should be applied by reference to the nature of the accusation, the nature of the evidence in support of the accusation, the severity of the punishment which conviction will entail, and whether the sureties are independent or indemnified by the accused. If this were all, English practice would not diverge far from that of the United States, but in recent years a gloss has been addedwhich seems to qualify the generality of the major proposition and which is treated as an exception, rather than as a reason for broadening

28 Magistrates' Courts Act, 1952, 15 \& 16 Geo. 6 \& 1 Eliz. 2, c. 55, §38(1).

29 Magistrates' Courts Act, 1952, 15 \& 16 Geo. 6 \& 1 Eliz. 2, c. 55, §105(4).

30 Archbold, Criminal Pleading, Evidence and Practice (31st ed. 1943).

31 Id. at 68. See also Kenny, Outzines of Criminat Law 449 (4th ed. 1909); 1 Stone's Justices Manual 1, 45 (91st ed. 1959). 
the principles upon which bail is granted. In a number of authoritative decisions it has been stressed by the Court of Criminal Appeal that before granting bail the magistrates should consider the known criminal record of the accused, and the probability that, if released on bail, he will commit crimes similar to those of which he has been convicted in the past and for which he has been committed for trial.

Thus Lord Goddard, L.C.J., observed in R. v. Gentry: ${ }^{32}$ "[A]s this Court has pointed out over and over again, it is most dangerous to grant bail to a man with a long record of convictions, unless the magistrates think that there is a real doubt as to his guilt, because he is sure, if he is committed to bail, to commit offences while he is on bail." This statement must, of course, be read with the judgment of the Court of Criminal Appeal in R. v. Phillips: ${ }^{33}$ "Some crimes are not at all likely to be repeated pending trial and in those cases there may be no objection to bail; but some . . . and housebreaking particularly . . . will very probably be repeated. . . ."34 In $R$. $v$. Phillips the judges criticised strongly magistrates who had granted bail to an accused who in effect had no answer to three charges against him, and who at his trial asked that nine further offences committed while on bail be taken into consideration ${ }^{35}$ in awarding sentence. ${ }^{36}$ And in $R$. v. Wharton ${ }^{37}$ the Court of Criminal Appeal reiterated that persons with bad criminal records should as a rule not be granted bail pending trial. $^{38}$

In short, though the main test in England as to whether bail should be granted is whether an accused will appear to stand his trial, the public interest is also considered in the somewhat limited context of assessing the risk of the accused committing offences while on bail. The learned author of "Comment on the New York Bail Study" ${ }^{3}$ observes: "It is significant that countries which use this reason for denying bail usually phrase it in terms of the fear that the defendant will commit 'another' crime while on bail, which, of course, assumes

3239 Crim. App. R. 195, 196 (Crim. App. 1955).

3332 Crim. App. R. 47 (Crim. App. 1947).

34 Id. at 48. See also R. v. Armstrong, 35 Crim. App. R. 72, 74 (Crim. App. 1951) (dictum).

35 A person who has pleaded guilty, or after conviction, may, in the U.K., ask that other crimes which he is prepared to admit should also be taken into account when sentence is imposed. If the court is willing to accede to this request, the prisoner on release after serving his sentence, is free to make a fresh start without fear of arrest and punishment for the crimes taken into consideration when he was sentenced.

3632 Crim. App. R. at 47-48.

37 [1955] CrIM. L. REv. (Eng.) 565 (Crim. App.). $132 / 1955$.

38 The opinion was circulated to clerks and justices. Home Office Circular No.

39 Foote, Forward: Comment on the New York Bail Study, 106 U. PA. L. REv. 685 (1958). 
that he is guilty of the first offense for which he is still to be tried." 40 The present writer would agree that any such phrasing is unfortunate, but is not unduly worried about the refusal of bail to a person of known criminal record accused on prima facie convincing evidence of another crime of the same species. Those who grant bail are not his judges in the instant case; and, in exercising their discretion in such a case, they may reasonably have regard to the public interest. It will, of course, involve hardship if on this particular occasion suspicion has focussed on the wrong man; indeed it is particularly sad when (as does sometimes happen) a man with a record, trying to go straight, is mistakenly accused; and it is undeniably the case that the imprisonment of a suspect handicaps the preparation of his defence. In England, however, the discretion to refuse bail is usually exercised after the magistrates have been satisfied that the prosecution has established a prima facie case.

So far as the present writer can judge there is little evidence that refusal of bail is used in England as a precautionary punishment of those who might be acquitted, nor, except in rare cases, is a suspect with substantial means favoured by contrast with the impecunious. The institution of professional bail providers does not flourish, and solicitors are discouraged by the Law Society of England from providing bail for clients. ${ }^{41}$

Criticisms have, certainly, been made of the English bail system in practice. ${ }^{42}$ A suspect in the initial stage of prosecution may well not be legally represented, ${ }^{43}$ and, in this event, magistrates not infrequently, perhaps, refuse bail if the police oppose it-even without stating reasons. This may give opportunity for the police to exercise pressure upon the uncooperative suspect, but there is little evidence that advantage is taken of it. Dr. Glanville Williams has suggested several reforms so far as English practice is concerned. He considers inter alia that there should be a speedier method of getting bail-by simple application which would impose on the court the duty to obtain copies of the depositions whereon they could decide the matter; that legal assistance should be provided whenever bail is in issue; that the police should always give their reasons in writing both to the accused and to the magistrates when they oppose bail; that the magistrates should be required to state their reasons for refusing bail and note the evidence on which these reasons are founded; and that procedure on appeal to

$40 I d$. at 685 n.4. The author cites as an example the Yugoslavia Code of Criminal Procedure, 1954, art. 182.

41 Law Society Gazette, Aug. 1952, p. 102.

42 See generally G. Williams, The Reform of the Law $186-90$ (1951).

43 Id. at 188 . 
the High Court should be simplified and expedited. ${ }^{44}$ These reforms could be beneficial in the very small number of cases in which the present system works hardship. Except, perhaps, in rare cases, where the police oppose bail, these reforms are designed to improve procedure rather than to correct abuses. An observer from Scotland-where there is no pre-trial hearing-may express mild surprise that, even after the justices have heard the evidence for the prosecution, they should rely as much as Dr. Glanville Williams suggests they do on police opinion regarding the merits of an application for bail. The matter might be different if, as Lord Goddard has suggested recently, the pre-trial hearing in England were to be abolished.

The distinctions between Scottish and English practice regarding the granting of bail are substantial, and in large measure due to differences in procedure. In particular, first, as has been noted, unlike the situation in England, prosecution in Scotland is almost always the concern of public prosecutors - the Crown Office and its representatives in the Sheriffdoms. Secondly, though in Scotland a suspect is brought before a judge (the Sheriff) ${ }^{45}$ at an early stage in proceedings, this is to secure judicial supervision of procedure ${ }^{46}$ and not to investigate the weight of the case against the accused. ${ }^{47}$ It follows, therefore, that in Scottish pre-trial procedure the prosecuting authorities, not the courts, have most of the information relevant to the granting or with-

$44 I d$. at $188-89$.

45 In Scots law the Sheriff or professional judge has virtually unlimited civil jurisdiction, and has criminal jurisdiction over most crimes. He can grant bail to a person accused of a crime which he may not try. The office of Sheriff in Scotland therefore clearly does not correspond to that of the English or American sheriff. See generally Sheriff S. G. Kermack's admirable survey The Law Courts of Scotland, 45 A.B.A.J. 451 (1959); SMITH, op. cit. supra note 7, at 679, 683.

46 For general explanation of judicial supervision of pre-trial procedure see authorities cited note 7 supra.

47 Before the Criminal Procedure (Scotland) Act, 1887, 50 \& 51 Vict., c. 35, came into force there is clear authority that the Sheriff, before committing an accused for trial, was expected to give "full and deliberate consideration of the declarations of the prisoners and the precognitions of the witnesses examined for the prosecution." See, e.g., Directors of City of Glasgow Bank v. H. M. Advocate, (1878) GR. (J.) 4, 7-8, [1878-1879] Sess. Cas. 4, 7-8 (Justiciary) (a Full Bench decision per L.J.-G. Inglis). Since the Criminal Evidence Act, 1898, 61 \& 62 Vict., c. 36, has made the accused a competent, though not compellable witness, it was provided by statute in 1908 that a suspect need no longer emit a declaration unless he so wished; and in practice suspects have very rarely exercised the right to make a declaration at judicial examination. Perhaps partly as a result of this development in modern practice and partly because of the increased personal responsibility committed to Sheriffs-Substitute and ProcuratorsFiscal by the 1887 act, the Sheriff before committing an accused for trial has not in general scrutinised the Crown precognitions. He has concentrated on the ProcuratorFiscal's petition for committal. Yet it has been competent for the Sheriff to peruse the precognitions, and until very recently (July-August 1959) the pro forma warrant for committal narrated that the Sheriff had considered this "Petition and the relevant Precognitions." The reference to "precognitions" has been omitted from the new pro forma warrants, thus bringing procedure into line with practice. On what authority this revision has taken place is yet unknown to the writer. It is, however, apparent that vestiges of a pre-trial judicial assessment of evidence survived until quite recently in Scottish practice. 
holding of bail. Considerable weight must therefore be given to the views of the Lord Advocate or his representatives. In practice the system works well in a small country of five million inhabitants with a strong professional tradition. The Scottish solution would not necessarily prove ideal in different conditions.

The history of bail in Scottish criminal law reaches back to very early times. Persons accused even of the gravest capital offences might be liberated upon providing security for their appearance to stand trial. ${ }^{48}$ Prior to the Act of $1701,4^{49}$ however, bail was allowed or refused in all cases at the court's discretion, and there were no safeguards against prolonged incarceration pending trial. Following upon the Claim of Right, 1689,"50 the Scottish Parliament in 1701 passed an "Act for preventing wrongous Imprisonments and against undue delayes in Tryals." This act, which is cumbrously expressed by modern standards, made a distinction between "bailable" and "non bailable" offences. "Bailable offences" were such as could not be dealt with by capital sentence. In respect of these the granting of bail was a right, and a maximum tariff was fixed according to the social status of the accused. The maximum amounts fixed by the act were twice increased during the 18th century to bring them into closer accord with contemporary economic circumstances. ${ }^{51}$ The Act of 1701 left undisturbed the existing discretion of the court to grant bail for "non bailable" crimes and offences-scil., offences which could competently be punished by death if the court so decided. These, of course, in the 18th century, comprised a wide range of criminal activity, including deforcement of revenue officers, thefts by habitual thieves, thefts by housebreaking of anything - however small in value-and so forth. If bail was refused in such cases, the accused was given a statutory right to speedy trial or (in default thereof) to unconditional liberation.

Modern practice, ${ }^{52}$ however, depends upon the Criminal Procedure (Scotland) Act, $1887,{ }^{53}$ and the Bail (Scotland) Act, 1888, ${ }^{54}$ supplemented to some extent by the nobile officium of the High Court of Justiciary - that is, the ultimate reserve of extraordinary or equitable

48 For history see II Hume, Commentaries on the Law of Scomland Respecting CrIAEs 87 (2d ed. 1819); Introduction to Scottish Legal History 430 (Stair Society Pub. 20, 1958).

49 Act for preventing wrongous Imprisonments and against undue delayes in Tryals, 1701, A.P.S., $x, 272$ c. 6.

50 A.P.S., ix, 37.

51 Act of 1724,11 Geo. 1, c. 26 ; Act of 1799,39 Geo. 3, c. 49.

52 This Article is not concerned with bail pending the hearing of an appeal after conviction.

$5350 \& 51$ Vict, c. 35 .

5451 \& 52 Vict., c. 36. 
jurisdiction inherent in the supreme criminal court. Now the granting or refusal of bail is in all cases a matter of discretion.

In solemn procedure, an accused must normally appear before a magistrate (usually the Sheriff) within forty-eight hours from the time of his apprehension-in most cases on the morning after arrest. At this stage, in modern practice the accused is not in fact examined judicially, though he could competently elect to be. At these proceedings-which take place privately before the Sheriff in chambers, with only the essential court and police officers and the accused and his law agent present-the Procurator-Fiscal moves the court to commit the accused either "until liberated in due course of law" or "for further examination." This implies that the Sheriff may either forthwith commit the accused for trial, or he may defer making such an order while further investigations are being made by the Crown authorities. In considering Scottish practice regarding bail, it may be convenient, therefore, to deal first with procedure before the suspect is committed for trial ("until liberated in due course of law") and thereafter to discuss the granting of bail after commitment for trial.

\section{Bail Before Final Commitment for Trial}

The Children and Young Persons (Scotland) Act, 1937,,55 contains special provisions under which senior police officers are empowered to release on bail juveniles who have been arrested. ${ }^{56}$ Generally, however, the first opportunity to apply for bail occurs when a person is brought before the Sheriff or a magistrate ${ }^{57}$-normally on the morning after arrest-for judicial examination. At this stage he is entitled to legal representation, and may immediately apply for liberation on his finding caution (security) ${ }^{58}$ The Procurator-Fiscal is entitled to be heard against any such application, ${ }^{59}$ and at this stage particular weight is given to his views. He will oppose release on bail if this would interefere with the enquiry, or if further charges are likely to be preferred against the accused. He alone has had opportunity of evaluating the evidence and the circumstances surrounding the case, and, if, in the exercise of his discretion, he asks for a further period of

551 Edw. 8 \& 1 Geo. 6 , c. 37.

56 Sections 24(2), 40(1). Comparable powers are conferred in England by the Children and Young Persons Act, 1933, 23 Geo. 5, c. 12, §32. Section 32(1) (c) of the English act has an interesting general proviso giving discretion to decline bail when release might defeat the ends of justice.

57 Though in a general sense a Sheriff may exercise magisterial functions, the term "magistrate," as used here, corresponds to municipal or police court judge in the United States.

58 Criminal Procedure (Scotland) Act, 1887, 50 \& 51 Vict., c. $35, \S 18$.

59 Ibid. 
up to eight days while further investigation is made, the court will not readily refuse his request, even though the accused may be kept in custody meanwhile. At this stage a statutory advantage is conferred on the prosecutor's attitude to bail. The Bail (Scotland) Act, $1888,{ }^{60}$ gives to the prosecutor alone a right of appeal against the sheriff's decision to grant bail before commitment for trial; no statutory right of appeal is given to the accused if bail is refused. He is, however, not necessarily without remedy.

The standard work on Scottish criminal procedure ${ }^{61}$ observes: "The length of time which may intervene between commitment for further examination and commitment for trial is not absolutely fixed, but ought as a general rule not to exceed eight days. This must be particularly observed in those cases where bail cannot be insisted upon till after commitment until liberation in due course of law" (scil., trial). ${ }^{62}$ Sheriffs, Procurators-Fiscal and Prison Governors are usually vigilant to see this practice strictly observed, but in an exceptional case within the writer's knowledge, a suspect was in fact held in custody for over a month without being committed for trial at all. He had been advised that he had no statutory right of appeal against the refusal of bail prior to committal. In a case such as this, however, in the writer's opinion, the High Court of Justiciary would have been prepared to exercise its paramount and overriding authority preserved by the Bail (Scotland) Act, 1888,63 to admit to bail any person charged with any crime or offence. Otherwise the law of Scotland would have no safeguard against indefinite incarceration. No other instance of detention for so long a period before commitment for trial is known to the writer, but the fact that it happened within the past three years perhaps suggests that express provision by statute should be made limiting the lawful period of detention "for further examination" without commitment for trial. Meanwhile, though habeas corpus is not, of course, an institution recognized in Scottish practice, the Scottish superior courts ${ }^{64}$ in the exercise of their nobile officium are vigilant to vindicate the liberty of the subject.

\section{Bail After Commitment for Trial}

If bail is refused before commitment for trial, the application may be renewed after such commitment, and the Sheriff may then at his discretion admit or refuse to admit the accused to bail. If he considers

6051 \& 52 Vict., c. $36, \S 5$.

61 Renton \& BRown, op. cit. supra note 7.

$62 I d$. at 43.

$6351 \& 52$ Vict., c. $36, \S 5$.

64 I.e., the High Court of Justiciary and Court of Session. 
that the case is appropriate for bail, the Sheriff is expected to fix a sum which the prisoner can find, but yet sufficient to deter him from absconding. The application for bail when the accused has been committed for trial may be opposed by the Procurator-Fiscal in the public interest. Both prosecution and defence may appeal from the Sheriff's decision to grant or refuse bail, and also if dissatisfied with the amount fixed. Though a number of Scottish cases refer to the "presumption of innocence," ${ }^{65}$ bail is not in fact granted on the ground of that or any other presumption. All accused persons-at least before trial-are "presumed to be innocent." Much wider considerations of public interest and securing the ends of justice are applied. Of course, when an accused applies for bail, he is entitled to have his application considered, and to have bail granted unless good reasons are put forward for its refusal; but the court's right of refusal is not confined to cases where, if bail were granted, the accused might abscond: in exercising its discretion, broadly speaking, the court will have regard to the nature of the crime alleged, the record of the accused and the attitude of the Crown. Among the considerations to be borne in mind are the risk that, if the accused were liberated on bail, he might intimidate witnesses or tamper with evidence generally; or alone or in association with others pursue criminal objects while on bail; or-as in cases of incest or brutal domestic assault-resort to the type of conduct which is alleged against him by the prosecutor. The categories are not, however, closed; and, since a general discretion is committed to the courts, they are free to consider all relevant factors for or against the granting of bail-as for example, that the accused has been subsisting for some time without any known way of obtaining money-such as earnings, private means, charity or public assistance.

The leading case, perhaps, is Mackintosh $v$. M'Glinchy, ${ }^{66}$ the decision of a Full Bench specially convened to determine whether the discretion to grant or refuse bail was general, or restricted to considering the danger that an accused might abscond-as might have been implied from the opinion of Lord Justice-General Dunedin in Rennie v. Dickson. ${ }^{67}$ The leading opinion of the Full Bench, delivered by L. J-G. Clyde, asserted the discretion of the court to grant or refuse bail in all cases-giving due weight to the views of the Lord Advocate who has at his disposal means of obtaining information about a crime and an accused. Lord Justice-General Clyde observed:

65 Young v. HMA, 1946 J.C. 5; HMA v. Quinn \& Macdonald, 1921 J.C. 61 ; Scott v. HMA, (1890) 2 White 570, [1890-1891] Sess. Cas. 15 (Justiciary).

661921 J.C. 75.

6719075 Adams 372, [1906-1907] Sess. Cas. 111 (Justiciary). 
"[W] hen appeal is made to a discretionary power, the only safe rule is that each case must be considered on its own merits, with the sole view to the public interest and to securing the ends of justice. . . . A good deal was said about the presumption of innocence. I prefer not to treat the matter as a question of presumption. The accused person has the right to ask for bail; he has the right to have his application considered; and, unless the Court has before it some good reason why bail should not be granted, bail ought to be allowed." 68

Apart from cases where there has been the danger of an accused tampering with evidence or exposing complainers to peril, ProcuratorsFiscal since this decision have opposed bail on three main grounds: first, where the accused has previously absconded when allowed bail, or where there is evidence of the accused's intention to abscond; secondly, where the accused has been liberated on bail, and is reported to the Procurator-Fiscal for an offence alleged to have been committed while at liberty which is either of a similar character to that originally charged against him or is of a serious nature; and thirdly, where the accused has a criminal record, is clearly (according to the prosecutor's information) carrying on a career of crime and has been released from prison shortly before the offence of which he is charged. Regarding the validity of the third of these grounds there was some uncertaintycertain judges accepting it and others refusing to do so. Practice has, however, become more uniform since the decision of the High Court in Wright. ${ }^{68}$ The accused in this case was charged with breaking into premises, forcing a safe by explosives and stealing a substantial sum of money. He had fifteen previous convictions. ${ }^{70}$ Bail had been granted by the Sheriff in the sum of $£ 150$, and from this decision the Crown appealed. The Lord Justice-General Clyde (son of the L.J-G. in Mackintosh v. M'Glinchy) observed, with the approval of Lords Carmont and Russell:

"The considerations which are relevant to that matter must vary from time to time with changing conditions. Today one material factor which ought always to be taken into account by a court in determining whether or not to grant bail is the previous record of the accused. This was recognized, and in my view properly recognized, by the Lord Justice-General in the case of MacDonald v. Clifford, 1952 J.C. 22 . It is in my opinion contrary to public interest that a man with a substantial criminal record should be given the opportunity pending his trial of enlarging and

681921 J.C. at $81-82$.

69 Nov. 7, 1958 (unreported).

70 The previous convictions disclosed a clear pattern of serious criminal conduct persisted in up to near the time of arrest. 
extending his criminal activities. Experience has shown that all too often that opportunity is taken if the opportunity is available. A criminal record accordingly is an important factor against the granting of bail. Indeed in some cases in itself it is sufficient to warrant the court in refusing bail. That would be particularly so where the list of previous convictions is substantial, and the latest conviction is of relatively recent date. Such factors emphasize the risk that the man may revert to his course of crime if released, and it appears to me that the public interest in such circumstances demands that that opportunity should not be given to him. In this case in my view the record alone is ample to justify the course which I recommend to your Lordships."

One factor which the judge (usually the Sheriff) considering bail is not in a position to assess in Scotland is the strength of the case against the accused. He is not conducting a pre-trial inquiry. The conduct of such an inquiry is the function of the Procurator-Fiscal, as directed by the Crown Office. The Lord Advocate and his representatives are concerned with the public interest, not only as prosecutors, but also in assessing in the first instance whether bail should be granted in any particular case. As prosecutors, moreover, it may be against the prosecutors' interest to oppose bail. In a complicated case of fraud, preparation of the case may well take longer than 110 days, and an accused who has been detained in custody for 110 days from the date of commitment is entitled to be set at liberty from prosecution. ${ }^{71}$

Though Scottish judges take into account a wider range of considerations than do English or American courts before awarding bail, the Scottish attitude towards bail is liberal. Refusal of bail as a precautionary punishment and as a form of economic discrimination may be discounted. If it is thought that release of an accused on bail is consistent with the public interest and the ends of justice, he will be released, though his means are very limited. His financial position is taken into account by the court-which may, however, in dubio also consider whether he has a permanent address. Persons accused of serious crimes have been released on quite small bail. If an appeal is taken from the Sheriff to the High Court on the amount of bail fixed, the tendency of the High Court is to show a liberal attitude and to reduce this sum to what the accused can in fact raise. There are in Scotland no professional granters of bail bonds. The accused, supported by his associates or relatives, finds the money, and the bail bond usually runs in the name of the solicitor for the defence. This practice sometimes results in dispute after trial as to whether the solicitor is entitled to retain as part of his fee the sum lodged originally as bail.

71 Criminal Procedure (Scotland) Act, 1887, 50 \& 51 Vict., c. 35, §43. See RENToN \& BRown, op. cit. supra note 7, at 83-84. 
Such disputes are unlikely to arise when a reputable lawyer is concerned-but those who live according to the standards of a subculture opposed to established law and order may find their legal advisers among those who are not ignorant of the law of the jungle. In the 1930's there was some evidence that in Glasgow the associates of a gang member in trouble might raise bail for him by intimidating shopkeepers and others to contribute. It does not appear that such unsavoury activity continues today.

There is no doubt that while an accused is in custody, preparation of the defence is impeded-especially if he wishes to trace witnesses of a type which would be unlikely to get in touch with a lawyer or other law abiding citizen. If the public interest will not permit bail, in Scotland all reasonable facilities are given to the prisoner and his advisers. According to Scottish practice the defence must be given ample notice before trial regarding productions ${ }^{72}$ and regarding the prosecution's witnesses. If these latter are reluctant to give their account to the defence on precognition, ${ }^{73}$ the Crown will assist the defence by showing them the Crown precognitions. In cases of murder, the Crown as a matter of established practice and courtesy invariably give copies of the prosecution's precognitions to the defence.

In Scotland there has been no complaint as to delay in the hearing of bail applications and appeals. An application must be dealt with within twenty-four hours of its presentation to a competent magistrate. ${ }^{74}$ So far as appeals are concerned, written notice is given by the party appealing as soon as the Sheriff has reached his decision on the application. If an appeal is taken by the prosecutor objecting to the granting of bail, the accused (if he has found bail as required) must nevertheless-unless the appeal has succeeded-be liberated after seventy-two hours (or in the Outer Hebrides, Orkneys or Shetlands ninety-six hours) after the application for bail was granted. This right to liberation is effective whether the appeal has been heard or not, unless the High Court orders the accused to be detained in custody pending consideration of the appeal. ${ }^{75}$

To summarise in conclusion the main contrasts between bail practice in Scotland, the United States, and England the writer would stress the following points. In the United States and in England the claim to bail or speedy trial is supported by habeas corpus, a procedure un-

72 Anglice, "exhibits." Productions include all documents and articles of whatsoever sort intended to be produced in evidence.

73 Precognitions in this context means the written record of a statement given by a witness to the Procurator-Fiscal as to the evidence which such witness can give at the trial.

74 Bail (Scotland) Act, 1888, 51 \& 52 Vict., c. $36, \S 2$.

75 Bail (Scotland) Act, 1888,51 \& 52 Vict., c. $36, \S 7$. 
known to modern Scots law, which has its own methods of securing the liberty of the subject. In America in theory, and in England, subject to one qualification, the courts direct their minds only to the question whether suspect, if bailed, will abscond; and, if the court is satisfied that he will not, they admit him to bail. In Scots law bail is a privilege, granted at discretion, after general review of the public interest. In England and America, before an accused is committed for trial, the evidence against him is led at a pre-trial hearing, so that the court which grants or refuses bail takes into account the strength of the prosecution's case. In Scotland, there is no pre-trial hearing; ${ }^{76}$ those who act in the public interest are most fully informed regarding the alleged crime and the antecedents of the accused, and they have the responsibility in the first place of agreeing to or opposing his application for bail. Much weight is given to their opinion. Their attitude is quite independent of the police. The Crown Office and the Lord Advocate's representatives exercise their discretion and responsibilities in accordance with a long-established, generous and humane tradition-which influences bail practice and criminal procedure in general. One can claim no more than that it works very well in a small country with a strict professional etiquette. On the presumption of innocence, American and English judges have ostensibly founded the right to bail; but, if this were really the kernel of the matter, all suspects would be bailed. As it is, in American practice it would seem that the presumption is sometimes invoked to let loose on the public, pending trial, a number of wealthy suspects who, whatever the presumption in their favour, do not act while on bail like innocent men. Scots law has now discarded the "presumption of innocence" theory in favour of a general discretion for a court to grant bail in all cases unless satisfied that this would be contrary to the public interest and the ends of justice. This solution, it is suggested, has much to commend it, though the writer considers that the conditions of persons held in custody before trial in Scotland could be greatly improved. Deprivation of liberty is a sufficient sacrifice to the public interest; discomfort or indignity, however, cannot be altogether avoided in the institutions where at present prisoners are confined in Scotland pending trial.

76 This Article does not discuss the problem of bail in summary procedure according to Scottish practice; on this see RENTON \& BRown, op. cit. supra note 7, at 232. The fundamental principles are the same, but as there is no preliminary petition for committal as in solemn procedure, the question of bail does not usually arise until the accused is before the court. Accordingly, by statute senior police officers are empowered to release on bail persons accused of minor offences pending their appearance in court. See also Kennedy v. Heatly, 1951 J.C. 118. 